Clipper Ships for San Francisco, "now rapidly loading at Pier Io, East River," is represented by a demure lady in a red crinolined dress apparently singing from a piece of sheet music to a stiffly enraptured sailor.

The figures, "I Io days to San Francisco!" " 96 days to San Francisco!" appear triumphantly at the head of some of the posters. I I 0 days was an amazingly good record. Only twenty-two passages from an Atlantic Port around Cape Horn in less than one hundred days are on record. Of these, seven were by ships built by the great artist in naval architecture, Donald McKay. His Flying Fish, with two of these record voyages over the "longest race course in the world" to her credit, is announced as "so well known that we only need to suggest the necessity of Shippers getting their goods on board early to avoid their being shut out." The owners of the Live Oak are less arrogant: "This magnificent Clipper is built all of Live Oak, and is the best ship now loading. Shippers will please examine this vessel, and send their goods immediately alongside."

The Civil War merely hastened the inevitable substitution of steam for sail. In concluding his Maritime History, Mr. Morison says of the clipper ship:

"Never, in these United States, has the brain of man fashioned so perfect a thing as the clipper ship. In her, the long-suppressed artistic impulse of a practical, hard-worked race burst into flower. The Flying Cloud was our Rheims, the Sovereign of the Seas our Parthenon, the Lightning our Amiens; but they were monuments carved from snow. For a brief moment of time they flashed their splendor around the world, then disappeared with the sudden completeness of the wild pigeon."

\title{
In ftlemoriam
}

THE Society has again lost one of its most valued members, in $\mathrm{Mr}$. Edward F. Albee, who was, until last October, president of the Keith-Albee vaudeville organization. Born at Machias, Maine, and descended from one of the original Minute Men, Mr. Albee startled his staid New England family by joining a circus. From this wagon show he went to $P$. T. Barnum, and was with such enterprises until he was twenty-eight.

In 1883 he and Benjamin F. Keith began their long connection, 
with a modest show in a store close to the old Adams House in Boston. Their interests were soon extended to other cities in New England, and the foundation was gradually laid for the chain of vaudeville theatres that stretches from coast to coast.

"Under Mr. Keith's and Mr. Albee's direction," says the Boston Globe, "the business of the Keith circuit grew rapidly, variety gave way to the more polite form of entertainment called vaudeville and then joined hands with the motion pictures. Such stars as Fred Stone, Al Jolson and George M. Cohan rose from the three-a-day to Broadway, and million-dollar temples to the art of entertainment arose.

"When the elder Keith died Albee shared control of the circuit with Paul Keith, and at the latter's death became its head. The name was changed to the Keith-Albee circuit and its houses extended from Boston to Chicago. In I 928 he acquired the Orpheum circuit, which covered the territory between Chicago and the West Coast, and formed the Keith-Albee-Orpheum circuit to play from Maine to California.

"In November, 1929, on formation of the Radio-Keith-Orpheum, he relinquished control and was succeeded as president by Hiram S. Brown."

The Business Historical Society, of which he was a member, deeply regrets losing his name from its rolls.

\section{Secretary's Column}

The Society appreciates the coöperation of its members and friends in securing for its archives many acquisitions of historical and current interest. The following additions have been received since the March publication of the Society Bulletin:

From Francis R. Hart, Vice-Chairman, Old Colony Trust Company, Boston, a photostat copy of "Proposition respecting the Coinage of Gold, Silver and Copper," I785.

From Edgar Higgins, New York, a file of photostat copies, clippings, papers and correspondence dealing with the development of Investment Trusts from their inception.

From Richard W. Hale, Boston, a file of correspondence, statistical material, charts and other data connected with the litigation between the New England Oil Refining Company, the Ballard Oil Company, and the estate of the late Warwick Greene. 